\title{
Numerical Modelling Based on Digital Elevation Model (DEM) Analysis of Debris Flow at Rinjani Volcano, West Nusa Tenggara, Indonesia
}

\author{
Muhammad Fatih Qodri ${ }^{1 *}$, Noviardi ${ }^{1}$, Al Hussein Flowers Rizqi ${ }^{1}$, Lindung Zalbuin Mase ${ }^{2}$ \\ 1Department of Geological Engineering, Institut Teknologi Nasional Yogyakarta, INDONESIA \\ Babarsari Rd., Caturtunggal, Depok, Sleman, Daerah Istimewa Yogyakarta \\ ${ }^{2}$ Department of Civil Engineering, University of Bengkulu, INDONESIA \\ WR. Supratman Rd., Kandang Limun, Bengkulu \\ ${ }^{*}$ Corresponding authors: fatihqodri@itny.ac.id
}

SUBMITTED 20 January 2021 REVISED 31 March 2021 ACCEPTED 16 April 2021

\begin{abstract}
Debris flow is a disaster occurring in cases where a sediment particle flows at high speed, down to the slope, and usually with high viscosity and speed. This disaster is very destructive and human life-threatening, especially in mountainous areas. As one of the world's active volcanoes in the world, Rinjani had the capacity to produce over 3 million $\mathrm{m}^{3}$ volume material in the 2015 eruption alone. Therefore, this study proposes a numerical model analysis to predict the debris flow release area (erosion) and deposition, as well as the discharge, flow height, and velocity. The Digital Elevation Model (DEM) was analyzed in ArcGIS, to acquire the Cartesian coordinates and "hillshade" form. This was also used as a method to produce vulnerable areas in the Jangkok watershed. Meanwhile, the Rapid Mass Movement Simulation (RAMSS) numerical modeling was simulated using certain parameters including volume, friction, and density, derived from the DEM analysis results and assumptions from similar historical events considered as the best-fit rheology. In this study, the release volume was varied at $1,000,000 \mathrm{~m}^{3}, 2,000,000 \mathrm{~m}^{3}$, and 3,000,000 $\mathrm{m}^{3}$, while the simulation results show movement, erosion, and debris flow deposition in Jangkok watershed. This study is bound to be very useful in mitigating debris flow as disaster anticipation and is also expected to increase community awareness, as well as provide a reference for structural requirements, as a debris flow prevention.
\end{abstract}

KEYWORDS Numerical modeling; DEM; Debris; RAMMS; Rinjani.

(c) The Author(s) 2021. This article is distributed under a Creative Commons Attribution-ShareAlike 4.0 International license.

\section{INTRODUCTION}

Nature is varied as well as highly unpredictable, and numerous reports show a high percentage of life loss suffered in climate-driven natural disasters, is due to landslides, particularly debris flow. Numerous lives and properties have been lost by this devastating disaster around the globe, including in Northern Venezuela (1999), Taiwan (1996), Columbia (1985, 1998) (Dowling and Santi, 2014). In Indonesia, debris flow disasters are usually caused by landslide and volcanic eruptions, are called lahars, for instance, Merapi Volcano debris in 2010 (Fathani and Legono, 2013), Sukabumi debris in 2019 (FITB, 2019), and numerous others.

Recently, risks arising from these debris' flows were not eliminated and have been difficult to reduce, due to the hazard's unpredictability and the difficulty to provide the warning. Currently, the mechanical and theoretical-based impact model analyses of debris flows are sparse (Scheidl et al., 2013). Therefore, improved predictive tools, and an understanding of the debris flow phenomena characteristics, are urgently required. Before this study, substantial studies have been conducted regarding landslides, focusing on debris flows in recent years, especially in terms of definition, main causes, and physical as well as mechanical attributes. According to Takahashi and Das (2014), debris flow is defined as the flow of saturated debris, usually with about $40-70 \%$ of the total volume as particles, and is characterized by extremely rapid mobility, 
caused by the water-particle ratio (Hungr et al., 2012). This mixture of particles and water moves due to gravity, and behaves as a continuum, as well as a ductile liquid with low strength, due to short distances between the particles and pores filled with water. Debris flows are usually triggered by rainfall (Hungr, 1995), and a large amount of material usually comes from the collapse, landslide, and barrier lakes deposited in river channels (Cui, 2000). These sources can generate debris flow, especially in the rainy season.

A report by Iverson (2005) described debris flow as a phenomenon occurring in cases where a mixture of water, mud, and gravel flows until the lump drifts at high speed down to the slope. This flow usually has high viscosity as well as speed, and is therefore very destructive, because the material transported is being passed along the river, thus the volume and energy are increasing. Debris flow can damage infrastructure and result in casualties. In this study, the research location is West Lombok Province of West Nusa Tenggara, particularly Jangkok Watershed, one of the main watersheds leading to Mataram City (Figure 1a). This study is focused on the morphology of mountains, where the materials is dominated by erupted deposits for Mount Rinjani.

According to BNPB (2016) the Rinjani Volcano erupted 12 times between 1846 and 2015, and this is a particular concern in this study. During the last decade, there have been several debris disasters on the island of Lombok, in 2006, 2012, 2014 and 2017 (Kristiawan and Sumaryono, 2020). Due to the Rinjani Volcano's active condition and abundance of volcanic material, there are concerns of eruption causing flooding as well as debris flow, and this condition is exacerbated by the high rainfall intensity. In 2015, an eruption occurred, resulting in increased material volume, from the eruption in Segara Anak Lake or the Rinjani Volcano Caldera. Thus, in cases where heavy rain occurs at the volcano's top, there is a possibility of debris flow occurring along the river, especially in Jangkok watershed. This study aims to simulate the debris flow's movement and impact in Jangkok watershed to make a mitigation plan for debris flow disasters and even in anticipation of the disaster. Several results are obtainable from the simulation, including the discharge, flow height, debris flow velocity, and possible flow distance. The result can be used to increase community awareness and provide a reference for structural as well as area development requirements.

\section{STUDY AREA}

\subsection{Geology and Geomorphology}

Based on the study by Mangga et al., (1994), the Lombok area's geology begins with the depositional Tertiary volcanic rocks, intermittently comprising the Kawangan and the Pengulung Formations, deposited in the Late Oligocene to the Early Miocene. The Pengulung Formation (Tomp) comprises volcanic rocks with limestone lenses and has a composition of sulfide ore as well as quartz veins, while the Kawangan counterpart comprises quartz sandstone, claystone, and breccias. These two units are penetrated by the intrusive rock (Tmi), containing basal dacite, diorite, and granodiorite in Middle Miocene. Meanwhile, in the Late Miocene, the Ekas Formation's limestone is deposited in non-conformity with The Pengulung (Tomp) and Kawangan (Tomk) Formations, in an open terrestrial environment. However, in the Pliocene to the Early Pleistocene, volcanic activity occurred from the Lombok volcanic group, forming the Kalipalung Formation (Tqp), comprising limestone and lava breccias, with Selayar Members (Tqs) containing alternating sandstones, tuff, claystone, as well as carbon inserts. The Kalipalung Formation (Tqp) is also connected to the Kalibabak counterpart (Tqb), containing breccias and lava. Subsequently, in the Late Pleistocene, the Lekopiko Formation (Qvl), dominating in the study area, was formed. This formation is related to the deposition of undifferentiated Volcanic Rocks containing lava, breccias and tuff, the result of the Pusuk - Nangi and Rinjani Volcanoes' activities (Qhv). Figure 1b shows Lombok Island's geology. 

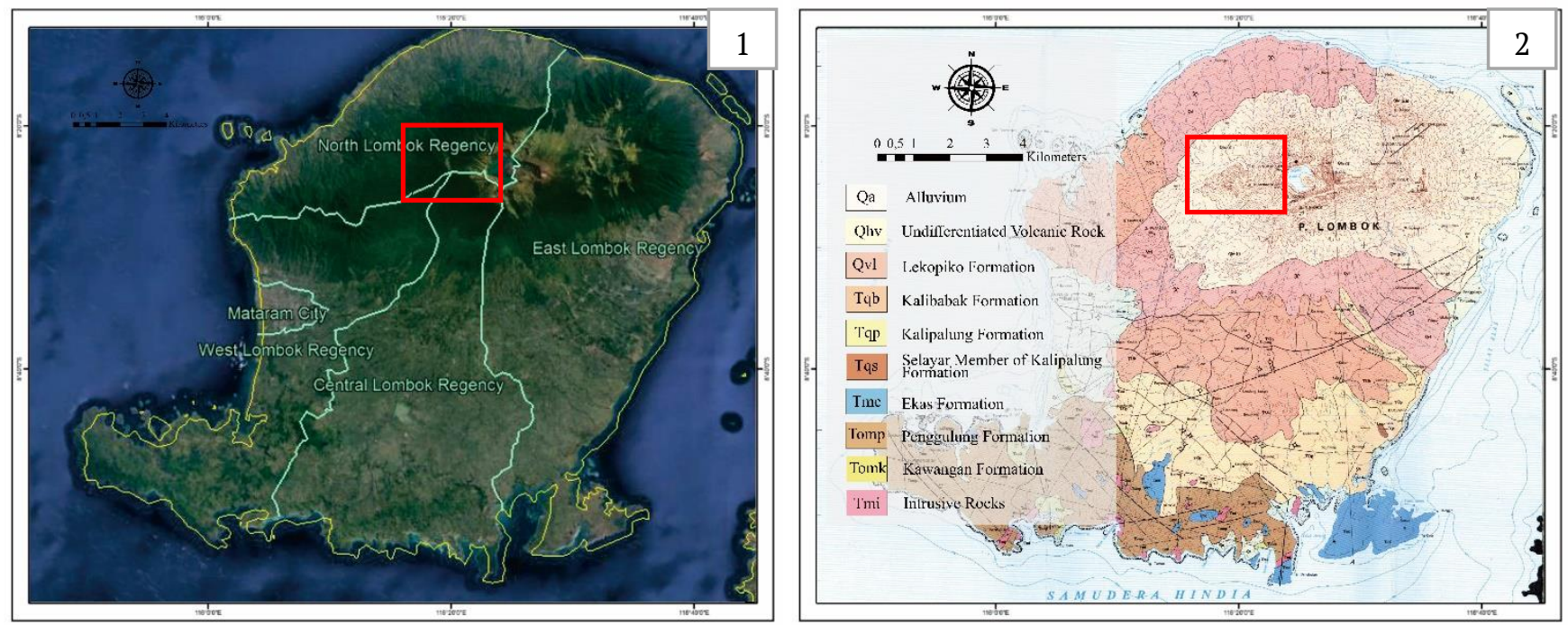

Figure 1. Lombok Island's (1) satellite image and (2) the geological map (red square is the research area) (modified from Mangga, 1994)

\subsection{Hydrological Condition}

Topographically, Rinjani Volcano has an altitude of 3724 meters above sea level. According to Hidayani (2015), Lombok Island has an annual rainfall of $676 \mathrm{~mm}$. Based on this value, the average river water discharge in each river basin is about $2838 \mathrm{~m}^{3} / \mathrm{s}$. The rainfall and river water discharge values are important parameters for performing debris flow modeling, used for RAMMS input, considering the cohesion value. Morphologically, the area around the Jangkok watershed is in the form of hills with steep slopes, having narrow or "V" shaped river bodies, especially in the upstream area. Figure 2 shows the river flows between 2 steep hillsides; thus, the river valleys are bound to experience landslides, due to high rainfall or earthquakes. Earthquakes are not only volcanic but, in some cases, also tectonic. A study by Qodri et al., (2021) reported tectonic earthquakes occurring far away have the capacity to influence soil, causing landslides. The drainage or Dendritic flow pattern (KemPUPR, 2019) is characterized by relatively flat sedimentary rock layers or nonuniform crystalline rock packages, with resistance to weathering. Consequently, landslides often occur around the river flow, where there are several villages, especially in the downstream areas. Several locations often report flooding in rivers, and this tends to be disastrous, in large numbers.

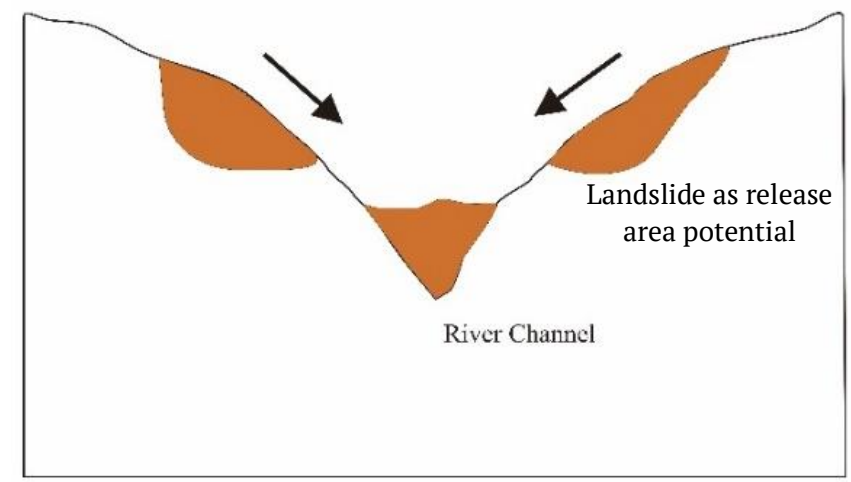

Figure 2. River Valley illustration at Jangkok Watershed

Generally, based on the previously described geological conditions, the study area is comprising loose volcanic material, resulting in the Rinjani Volcano's previous eruption. From this information, the cohesion value is regarded as zero, because loose material dominance is considered as cohesionless (Cui et al., 2017).

\section{METHODS}

This section presents the methods used to accomplish the study's aim. Basically, the potential debris flow is analyzable using numerical models. However, the applicable parameters ought to be established, prior to the numerical modeling. Also, several parameters must be determined, using another application. This process involves analysis of similar historical events and assumptions from previous studies, to select the best-fit rheology a well as 
parameters. As the study's scope, the Jangkok watershed and historical events in Lombok Island are considered to acquire these parameters. Fundamentally, this numerical modeling involves two steps, the Digital Elevation Model (DEM) Analysis, followed by numerical modeling in RAMMS.

\subsection{Digital Elevation Model Analysis using ArcGIS}

Digital Elevation Mode is the form for earth surface, containing a set of points with algorithm and coordinates (Tempfli, 1991). A Digital Elevation Model is analyzed using a geographic information systems (GIS) platform, and this application is adopted to express the form of satellite topography images, over the study area. Figure 3 shows the generation process.

In this study, the Digital Elevation Model (DEM) with a $25 \mathrm{~m}$ spatial resolution was generated to obtained slope angles and elevations. The raw data satellite topography image is downloaded from the site http://tanahair.indonesia.go.id. (BIG, 2020), to acquire the DEM. Subsequently, the DEM proceeds to ArcGIS application and ASCII raster file extraction. ArcGIS is a software package comprising GIS software products manufactured by ESRI. Furthermore, DEM is processed by setting the Spatial Reference (coordinates of WGS1984) and Data Frame Properties. This reference must be a Cartesian coordinate and performed to correct the coordinates according to actual conditions. This is followed by "Hillshading", using the "HillShade (3D Analyst)" ArcToolbox, to generate 3D shapes/Hillshade form. The DEM data processed in this application is then inputted in the RAMMS, for the next simulation. Figure 4 shows the landslide susceptibility zone according to geological data as well as slope, obtained using the generated debris flow's DEM files within the study area, and this map serves as the release area guide. Instantaneous landslide is able to initiate debris flow due to gravity, based on the frictional resistance, and flow depth is a value often measured with an observation station or estimated by geomorphic evidence.

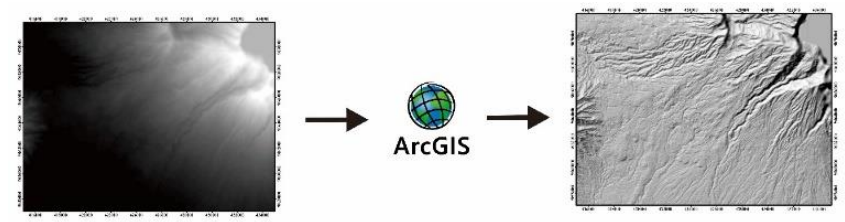

Figure 3. Topographically Digital Elevation Model generation from satellite topography images

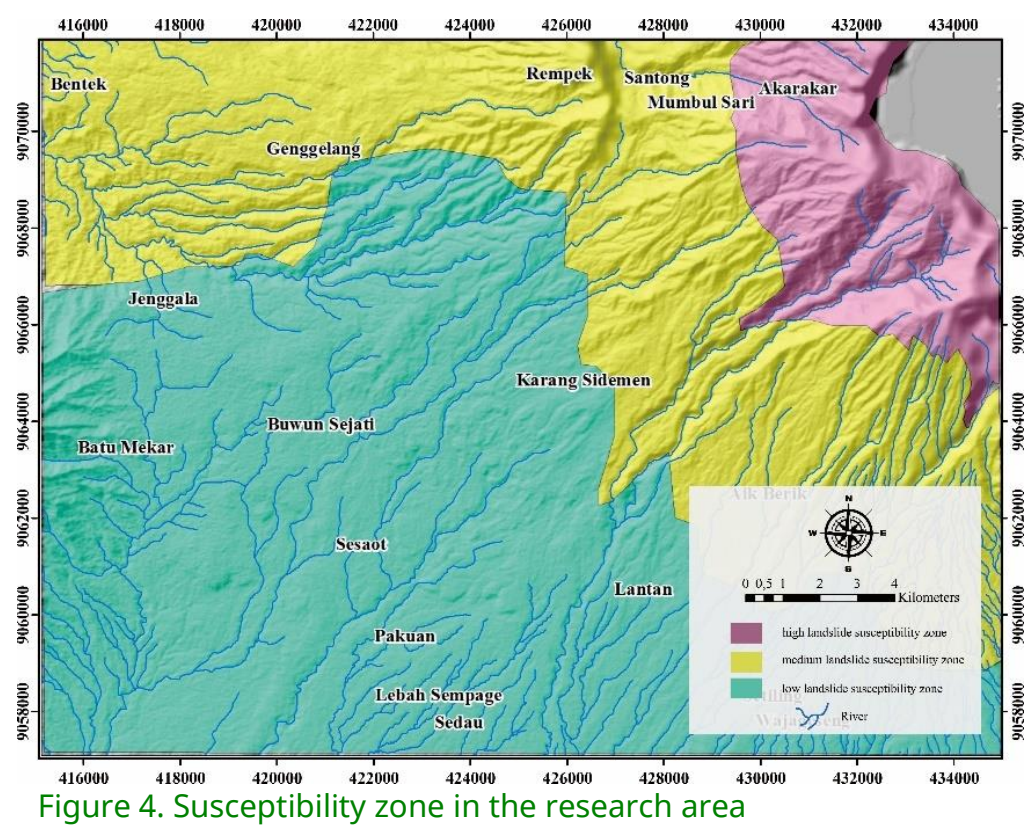




\subsection{Numerical Modeling using RAMMS}

Rapid Mass Movement Simulation (RAMSS) was originally created by a team of experts from the WSL Institute for Snow and Avalanche Research SLF in Switzerland, to simulate snow avalanches, and was released in 2011. However, this application has recently been developed for application in modeling debris flow, especially lahar and rockfall. The RAMMS model is already being used in Switzerland and other parts of the world for debris flow hazard analysis. Bartelt et al., (2015), stated the program was designed to aid debris flow disaster mitigation, and flow types, ranging from granular to muddy debris flows and floods, have been observed. The program utilizes the Voellmy-Salm fluid flow continuum model, based on the Voellmy friction model (Salm, 1993). For numerous years, this model has initiated wide application in the simulation of mass movements for many years and a set of standard parameters are available. The debris flow is described by a hydraulic-based depth-averaged continuum model, dividing the friction resistance into two, dry-Coulomb type friction scaling with normal stress, and viscousturbulent friction. In debris flow simulation, RAMMS actually uses a one-phase approach (Voellmy-Fluid), and this model assumes no shear deformation. Thus, the flow body moves as a plug with the same mean velocity $(U)$ all over the flow depth $(H)$. Equation (1) shows a simplified representation of the total resistance, $S$.

$S=\mu \rho H g \cos \emptyset+\frac{\rho g U^{2}}{\xi}$

Where, $\rho$ represents the bulk density, $g$ denotes gravitational acceleration, $\varnothing$ connotes the slope angle, $H$ indicates mean flow height, and $U$ signifies the mean flow velocity (Christen et al., 2010). The Voellmy model accounts for the solid phase's resistance ( $\mu$ is often expressed as the internal shear angle's tangent) and a viscous or turbulent fluid phase ( $\xi$ was introduced by Voellmy, using hydrodynamic arguments). In addition, the friction coefficients are responsible for the flow's behavior. Conversely, the viscous or turbulent fluid phase's resistance (the term, including $\xi$ ) prevails for a faster-moving flow (Bartelt et al., 2015). Usually, the normal stress on the running surface, $\rho \mathrm{Hg} \cos \emptyset$, is summarize in symbol $\mathrm{N}$. These equations were continuously developed until RAMMS was modified by adding cohesion (C). Thus, the equation becomes Equation (2), as shown below.

$\mathrm{S}=\mu \mathrm{N}+(1-\mu) \mathrm{C}-(1-\mu) \operatorname{Cexp}\left(\frac{-\mathrm{N}}{\mathrm{C}}\right)++\frac{\rho \mathrm{gU}^{2}}{\xi}$

The main steps in RAMMS simulation begin from topography data defined by DEM. These DEM/topography files are processed in ESRI ASCII grid format (.txt), and ought to be in a Cartesian coordinate system (Christen et al., 2010). Figure 5 shows the next step, defining the release area, affected watershed, and hydrograph parameters. The release area is a geometry of potential debris material sources. Debris flow is defined using either a block release (landslide release) or a hydrograph (flow discharge as a function of time). However, in this study, a block release was selected, because the initial release height was adjusted according to the corresponding total volume. The deposit volume as the debris flow's release area is obtained from the high landslide susceptibility zone, especially in the high slope. A report by BNPB (2016) showed the average run-out volume in all Rinjani's watershed, is about 4.5 million $\mathrm{m}^{3}$. In this study, the volume was varied between $1,000,000 \mathrm{~m}^{3}, 2,000,000 \mathrm{~m}^{3}$, and $3,000,000 \mathrm{~m}^{3}$ (Ayotte and Hungr, 2000). A volume above $3,000,000 \mathrm{~m}^{3}$ shows an overflow result, where debris exceeds the watershed's volume.

In accordance with Deubelbeiss and Graf (2013), both block release and hydrographs are placeable at a point, where erosion no longer occurs. At this point, the total volume is possible, and the velocity is close to maximum speed. The peak discharge is also assumed to reach a maximum after 5 seconds. Normally, simulations in debris flow, are classified as either un-channelized, for hillslope debris flows or shallow landslides, or as channelized debris flows, acquired in regions where torrents limit the flow paths and the debris material mainly follows the torrent channel (Bartelt et al., 2015). Therefore, this 
study utilized the channelized debris flow as consideration. Meanwhile, the hydrograph's end was automatically computed in cases where the total volume and peak discharge were provided. With regard to the Voellmy friction coefficients, applying $\mu=0.2$ for the dry Coulomb type friction and $\xi=200 \mathrm{~m} / \mathrm{s}^{2}$ for the viscous-turbulent friction as initial values, is recommended, in cases where the flow type is unknown. $\mu$ is stated as $\tan \alpha$, where $\alpha$ is the flow path's average slope angle, and normally ranges between 0.01 and 0.4 . With regard to the turbulent friction term, $\xi$, small values are reported for granular flows (100-200 $\mathrm{m} / \mathrm{s}^{2}$ ), while muddy flows are associated with larger values $\left(200-1000 \mathrm{~m} / \mathrm{s}^{2}\right)$ (Bartelt et al., 2015). In RAMMS simulation, several default values are already specified, and these values were not changed in this study. Also, the density of the flow was set to $2000 \mathrm{~kg} / \mathrm{m}^{3}$ in all simulations. Furthermore, the pressure coefficient was set to 1 , and corresponds with a hydrostatic stress distribution, while the stopping criteria were set to $5 \%$ momentum, the default value. In RAMMS, the stopping criteria's threshold values are between 1-10\%, while momentum is based on a summary of all the grid cell's momenta. The simulation debris flow is regarded as stop, in cases where the momentum percentage is smaller, compared to the defined threshold. Table 1 shows a summary of the parameters inputted in RAMMS application.

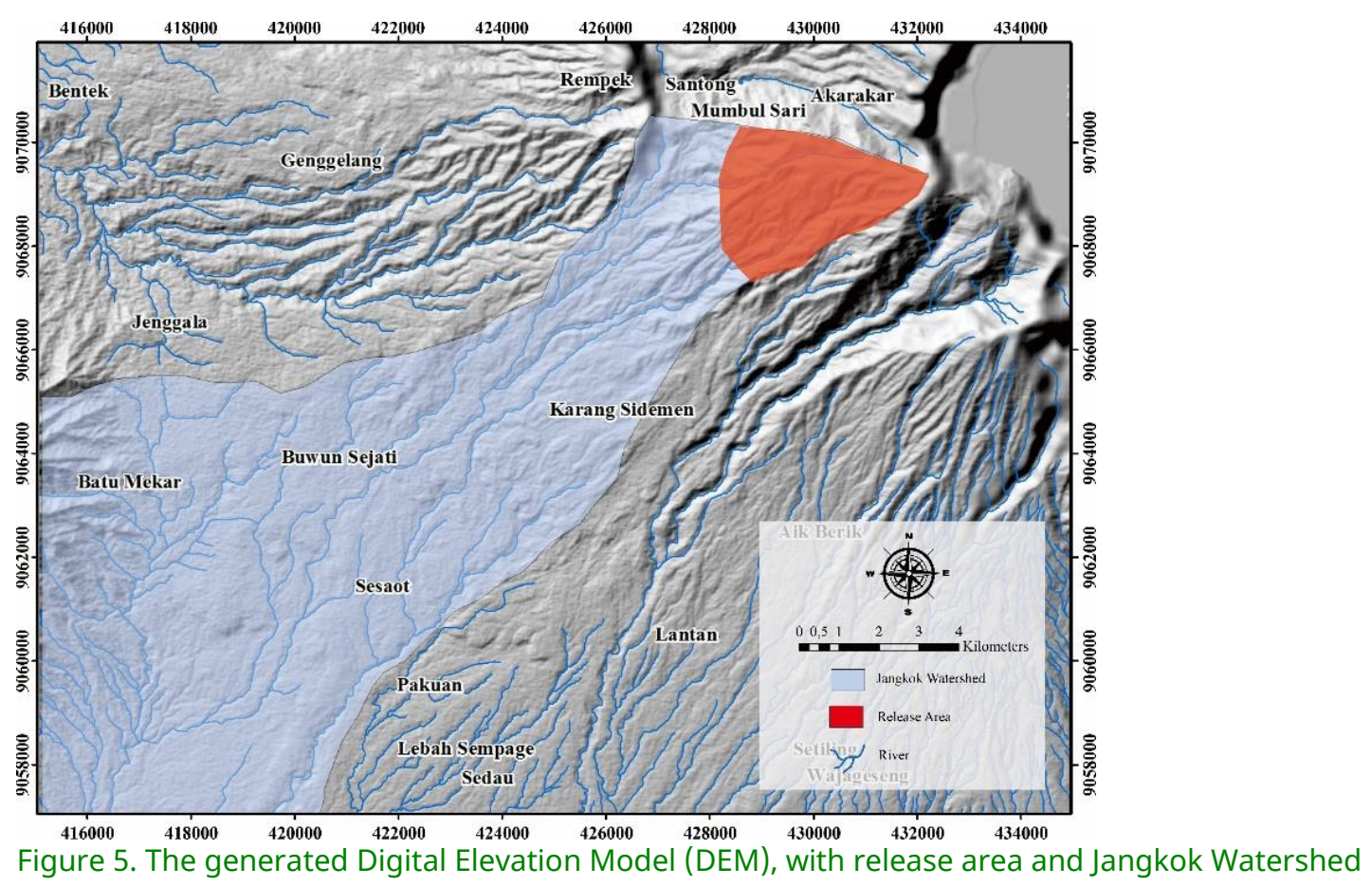

Table 1. Names of styles used in the study

\begin{tabular}{lll}
\hline Parameter & Value & Notes \\
\hline DEM & $8.29 \mathrm{~m}$ & http://tanahair.indonesia.go.id \\
Simulation Step & $1000 \mathrm{~s}$ & Default RAMMS \\
Dump step & $5.00 \mathrm{~s}$ & Default RAMMS \\
Density & $2000 \mathrm{~kg} / \mathrm{m}^{3}$ & Ayotte and Hungr, 2000 \\
Lambda & $1.00 \mathrm{~m}$ & Bartelt et al., 2015 \\
Rainfall & $676 \mathrm{~mm} / \mathrm{year}$ & Hidayani, 2015 \\
Rain debit & $2838 \mathrm{~m} / \mathrm{s}$ & Hidayani, 2015 \\
Material Volume & $1,000,000 \mathrm{~m}^{3} ; 2,000,000 \mathrm{~m}^{3} ; 3,000,000 \mathrm{~m}^{3}$ & Ayotte and Hungr, 2000 \\
$\xi$ & $700 \mathrm{~m} / \mathrm{s}^{2}$ & Bartelt et al., 2015 \\
$\mu$ & 0.01 & Bartelt et al., 2015 \\
Release & Block Release & Default RAMMS \\
\hline
\end{tabular}




\section{RESULTS}

In this study, the DEM and RAMMS were able to analyze debris flow cases in Jangkok watershed. Figure 6 shows the modeled debris flow, indicating different results obtained with changes in volume. Schraml et al., (2015) explained variation of release was bound to cause little variation in the outputs by RAMMS. The results varied mostly in distance, followed by velocity, pressure, discharge, and outflow. For a block release, all volumes are set to motion at the same time, to explain naturally the different velocities and outflow.

At a $1,000,000 \mathrm{~m}^{3}$ input volume, the maximum flow velocity was found to be $20.89 \mathrm{~m} / \mathrm{s}$, while the discharge flow and maximum pressure were $5,199.47 \mathrm{~m}^{3} / \mathrm{s}$ and $872.8 \mathrm{kPa}$, respectively, resulting in a 218,025.75 $\mathrm{m}^{3}$ final outflow volume.

At a 2,000,000 $\mathrm{m}^{3}$ input volume, the maximum flow velocity was found to be $27.06 \mathrm{~m} / \mathrm{s}$, while the discharge flow and maximum pressures were
$28,839.60 \mathrm{~m}^{3} / \mathrm{s}$ and $1,465.47 \mathrm{kPa}$, respectively, resulting in a $553,780.35 \mathrm{~m}^{3}$ final outflow volume.

At a 3,000,000 $\mathrm{m}^{3}$ input volume, the maximum flow velocity was found to be $34.7 \mathrm{~m} / \mathrm{s}$, while the discharge flow and maximum pressures were $30,795.74 \mathrm{~m}^{3} / \mathrm{s}$ and $1,836.18 \mathrm{kPa}$, respectively, resulting in a $618,302.26 \mathrm{~m}^{3}$, final outflow volume. Table 2 shows a summary of the numerical modeling results.

With regard to the graphs of discharge and flow height versus distance (Figure 7 ), the runway length at a 1,000,000 $\mathrm{m}^{3}$ input volume, debris flow is capable of reaching $\pm 6.5 \mathrm{~km}$ from the release area, with a $2.28 \mathrm{~m}$ average flow height. Meanwhile, at a 2,000,000 $\mathrm{m}^{3}$ input volume, debris flow is capable of reaching $\pm 8 \mathrm{~km}$ from the release area, with a $2.86 \mathrm{~m}$ average flow height. Similarly, at a 3,000,000 $\mathrm{m}^{3}$ input volume, debris flow is capable of reaching \pm 8.5 $\mathrm{km}$ from the release area, with a $3.55 \mathrm{~m}$ average flow height.
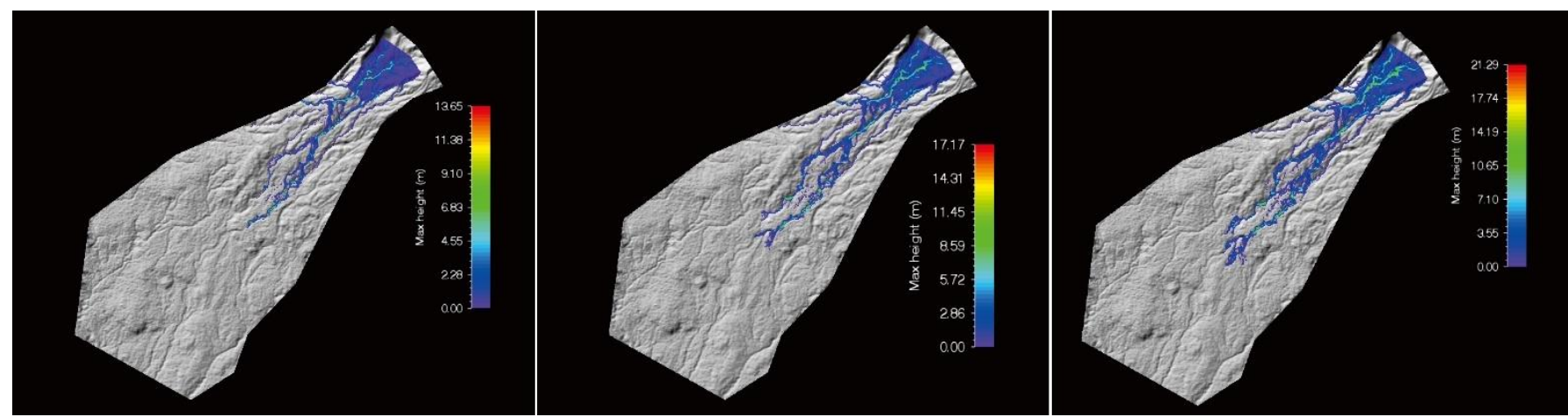

Figure 6 . The model results of RAMMS
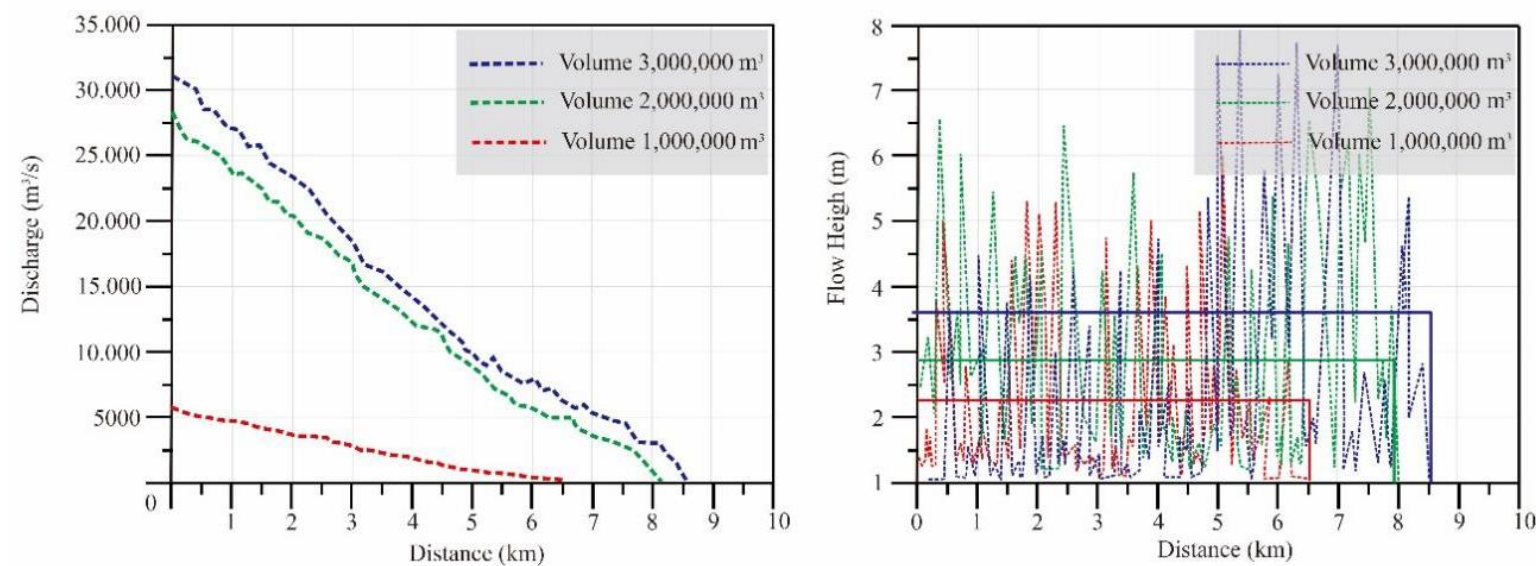

Figure 7. The result of discharge and flow height versus distance 
Table 2. The RAMMS numerical modeling results

\begin{tabular}{lllllll}
\hline Volume $\left(\mathrm{m}^{3}\right)$ & $\begin{array}{l}\text { Velocity } \\
(\mathrm{m} / \mathrm{s})\end{array}$ & $\begin{array}{l}\text { Pressure } \\
(\mathrm{KPa})\end{array}$ & $\begin{array}{l}\text { Discharge } \\
\left(\mathrm{m}^{3} / \mathrm{s}\right)\end{array}$ & $\begin{array}{l}\text { Average Flow } \\
\text { Height }(\mathrm{m})\end{array}$ & Outflow $\left(\mathrm{m}^{3}\right)$ & $\begin{array}{l}\text { Distance } \\
(\mathrm{km})\end{array}$ \\
\hline $1,000,000$ & 20.89 & 872.80 & $5,199.47$ & 2.28 & $218,025.75$ & 6.50 \\
$2,000,000$ & 27.06 & $1,465.47$ & $28,839.60$ & 2.86 & $553,780.35$ & 8.00 \\
$3,000,000$ & 30.30 & $1,836.18$ & $30,795.74$ & 3.55 & $618,302.26$ & 8.50 \\
\hline
\end{tabular}

\section{CONCLUSION}

This study concluded DEM and RAMMS are sophisticated modeling tools suitable for debris flow estimation. Based on the results of modeling in Jangkok Watershed, West Lombok Regency, debris flow occurrence is able to hit up to $\pm 8.5 \mathrm{~km}$ from the release point, with a $3.55 \mathrm{~m}$ average flow height, in a volume of $3,000,000$ $\mathrm{m}^{3}$. In addition, the flow is able to hit up to \pm 8 $\mathrm{km}$ and $6.5 \mathrm{~km}$, with average flow heights of 2.86 $\mathrm{m}$ and $2.28 \mathrm{~m}$, respectively, at volumes of $2,000,000 \mathrm{~m}^{3}$, and $1,000,000 \mathrm{~m}^{3}$, respectively. The area in Jangkok watershed was also concluded to possess a medium disaster susceptibility level to debris flow, according to BNPB standards (2016).

\section{DISCLAIMER}

The authors declare no conflict of interest.

\section{AVAILABILITY OF DATA AND MATERIALS}

All data are available from the author.

\section{ACKNOWLEDGMENTS}

The authors are grateful to the Geological Engineering Department, Institut Teknologi Nasional Yogyakarta, for the provision of support, through the collaboration research scheme with the University of Bengkulu.

\section{REFERENCES}

Ayotte, D. and Hungr, O., 2000. Calibration of a runout prediction model for debris-flows and avalanches. In Debris-flow hazards mitigation: mechanics, prediction, and assessment (pp. 505514).

Badan Informasi Geospasial (BIG). Geospasial Untuk Negeri. Available at: http://tanahair.indonesia.go.id. [Accessed 1 Maret 2021].

Bartelt, P., Bühler, Y., Christen, M., Deubelbeiss, Y., Graf, C., McArdell, B. W., and Schneider, M., 2015. RAMMS-DF User Manual. WSL Institute for Snow and Avalanche Research SLF, Davos, Birmensdorf, Switzerland

Christen, M., Kowalski, J. and Bartelt, P., 2010. 'RAMMS: Numerical simulation of dense snow avalanches in three-dimensional terrain'. Cold Regions Science and Technology, 63(1), pp. 1-14.

Cui, P., 2000. The classification of Chinese debris flows. Edited by BX Tang. Commercial Press, Beijing, pp.60-71.

Cui, Y. F.; Zhou, X. J.; Guo, C. X. 2017. Experimental study on the moving characteristics of fine grains in wide grading unconsolidated soil under heavy rainfall. Journal of Mountain Science, vol. 14, no. 3, pp. 417-431.

Deubelbeiss, Y. and Graf, C., 2013. Two different starting conditions in numerical debris flow models-Case study at Dorfbach, Randa (Valais, Switzerland). GRAF, C. (Red.) Mattertal-ein Tal in Bewegung. Publikation zur Jahrestagung der Schweizerischen Geomorphologischen Gesellschaft, 29, pp.125-138.

Dowling, C.A. and Santi, P.M., 2014. Debris flows and their toll on human life: a global analysis of debris-flow fatalities from 1950 to 2011. Natural hazards, 71(1), pp.203-227.

Fakultas Ilmu dan Teknologi Kebumian ITB (FITB). Ganasnya Longsor dan Aliran Bahan Rombakan. Available at: https:/fitb.itb.ac.id/2019/01/ganasnya-longsor- 
dan-aliran-bahan-rombakan/. [Accessed 30 December 2020].

Fathani, T.F. and Legono, D., 2013. The application of monitoring and early warning system of rainfall-triggered debris flow at Merapi Volcano, Central Java, Indonesia. In Progress of Geo-Disaster Mitigation Technology in Asia (pp. 263-275). Springer, Berlin, Heidelberg.

Hidayani, N., 2015. Pemetaan Rawan Banjir Bandang Daerah Aliran Sungai Sambelia Kecamatan Sambelia Kabupaten Lombok Timur NTB, Yogyakarta: Doctoral Dissertation Report, Universitas Gadjah Mada.

Hungr, O., 1995. A model for the runout analysis of rapid flow slides, debris flows, and avalanches. Canadian Geotechnical Journal, 32(4), pp. 610623.

Hungr, O., Leroueil, S. and Picarelli, L., 2012. Varnes classification of landslide types, an update. In 11th International Symposium on Landslides (Vol. 1, pp. 47-58). CRC Press Taylor\&Francis Group.

Iverson, R.M., 2005. Debris-flow mechanics. In Debris-flow hazards and related phenomena (pp. 105-134). Springer, Berlin, Heidelberg.

Kristiawan, Y., \& Sumaryono, S., 2020. Pemodelan Aliran Bahan Rombakan (Debris Flow) di Kecamatan Sambelia, Kabupaten Lombok Timur, Nusa Tenggara Barat. Jurnal Lingkungan dan Bencana Geologi, 11, 49-62.

Mangga, S., Atmawinata, S., Hermanto, B., Setyogroho, B., and Amin, T.C., 1994. Peta Geologi Lembar Lombok, Nusa Tenggara. Pusat
Penelitian dan Pengembangan Geologi, Indonesia.

National Agency for Disaster Management (BNPB), 2016 Rencana Kontijensi Menghadapi Ancaman Bencana Erupsi Gunungapi Rinjani/Barujari Provinsi Nusa Tenggara Barat, Mataram.

Salm, B., 1993. Flow, flow transition and runout distances of flowing avalanches. Annals of Glaciology, 18, pp.221-226.

Scheidl, C., Chiari, M., Kaitna, R., Müllegger, M., Krawtschuk, A., Zimmermann, T. and Proske, D., 2013. Analysing debris-flow impact models, based on a small-scale modelling approach. Surveys in Geophysics, 34(1), pp.121-140.

Schraml, K., Thomschitz, B., McArdell, B.W., Graf, C. and Kaitna, R., 2015. Modeling debrisflow runout patterns on two alpine fans with different dynamic simulation models. Natural Hazards and Earth System Sciences, 15(7), pp.1483-1492.

Takahashi, T. and Das, D.K., 2014. Debris flow: mechanics, prediction, and countermeasures. CRC press.

Tempfli, K., 1991. DTM and differential modelling in: Proceedings ISPRS and OEEPE joint workshop on updating data by photogrammetric records. by PRT Newby. OEEPE publication, 27, pp.193-200.

The Ministry of Public Works and Housing, BWS Nusa Tenggara I (KemPUPR), 2019, Buku Data dan Informasi Pengelolaan Sumber Daya Air WS Lombok dan WS Sumbawa Tahun 2019, Jakarta. 
[This page is intentionally left blank] 